International Journal of ASRO

Volume 9, Number 2, pp. 133-140

July-December 2018

\title{
DESIGN AND MANUFACTURE OF INDONESIAN NAVAL WARSHIP TECHNICAL CONDITION REPORT AND INVENTORY INFORMATION SYSTEM
}

\author{
Zainal Syahlan, Endro Prasetijoadi, Fatkulil Aswar Mahia, Adi Bandono \\ Sekolah Tinggi Teknologi Angkatan Laut, STTAL Surabaya Indonesia
}

\begin{abstract}
Information system is a system within an organization that meets the needs of processing daily transactions, supports operations, is managerial and strategic activities of an organization and provides certain external parties with reports needed in inventory management which includes managing data in and out, data borrowers of goods and data including the condition of defense equipment that is still suitable for use or damaged conditions still use journal books and still rely on Microsoft office. Based on the above problems, it is necessary to design and manufacture an inventory information system and report technical conditions in the KRI environment that can assist in the creation, implementation and development of an inventory information system, avoiding errors in storing data files of goods, the person in charge of the inventory can quickly present data on the condition and readiness of the ship as material for reports for the head of the department to the commander and facilitate reporting and new commander's policies and reporting to the unit. The technical condition report is an official regulation in order to carry out routine technical reports of all levels at the KRI level with the aim of reporting the ship's readiness both inventory reports and ship material reports as routine technical instructions carried out by the top command level ranks in order to prepare all ships preparedness for assignment military and non military.
\end{abstract}

Keywords: Inventory Information System, Technical Condition Report.

\section{INTRODUCTION}

Information technology is one technology that is developing rapidly at this time, with advances in information technology accessing data or information available can take place quickly, efficiently and accurately. The development of science and technology encourages the development of information systems, one of which includes an inventory information system. Professionalism and quality improvement carried out in order to realize the World Class Navy that has been proclaimed by leaders to all ranks of the command below demands all elements including that $\mathrm{KRI}$ must be able to make information technology as an increase in work professionalism. Republic of Indonesia ships or commonly abbreviated as $\mathrm{KRI}$ are defense equipment (the main tool of the system weaponry) owned by the Navy and is one of the core forces in the ranks of the Eastern Indonesian Fleet Command. In carrying out its duties and functions as a stronghold of maritime and one of the components of national development, in its role $\mathrm{KRI}$ is able to place an inventory as a supporting tool for data processing on the conditions and defense equipment readiness to support the implementation of military and non-military operations. in the management of inventory which includes data management of goods in and out, goods borrowers and data including inventory conditions that are still feasible to use or damaged conditions still use journal books for recording and still rely on the Microsoft office.

In the implementation of technical guidelines in each $\mathrm{KRI}$ element there are 4 (Four) Departments including:

1). Department of Operations (Dep. Ops). 
2). Department of Electronics (Dep. Eka).

3). Department of Machinery (Dep Mes)

4). Department of Logistics (Dep. Log).

In each department there is a Head of Department (Kadep) who plays an important role as the person in charge of members, all inventory and in and out of goods as well as reporting damage to goods in each department.

Inventory in the KRI that we have met today is still not optimal in terms of data storage and data administration systems including:

1). Data storage is still conventional, ie checking data relying solely on Microsoft and journal books.

2). Lack of orderly administration of lending and returning goods due to frequent reduction in inventory of goods. 3). As a result of delays in decision making from the head of the department due to lack of detailed information from member reporting (Inventory Tool Holder).

4). Frequent archiving of files is lost because of piling up of files

5). Limited space and time in obtaining appropriate inventory information at that time also makes reporting to commanders about the conditions and readiness of sewaco and material less efficient to prepare for the assignment.

Based on the above problems, it is necessary to design and manufacture an inventory information system and report technical conditions in the $\mathrm{KRI}$ environment that can assist in the creation, implementation and development of an inventory information system, avoiding errors in storing goods data files, and the person in charge of the inventory can be quickly presents data on inventory conditions, reporting to department heads and commanders as well as ship readiness for military and non military operations, as reports for department heads to commanders and facilitate reporting of commanders in the recovery of policies and decisions for reporting to unit staff and then forward it to Disharkap (ship maintenance service).

Based on the background of the problem above, then the problem can be formulated, namely how to design and manufacture an inventory system and report technical conditions in the KRI environment?
The purpose of this study is the design and manufacture of an inventory system and report technical conditions in the $\mathrm{KRI}$ environment. With this system can help the process of managing file recording and storage as well as borrowing and returning inventory items effectively, managing data in and out of inventory, making it easier to report damage to inventory items and reporting technical conditions, avoiding mistakes in making decisions from the commander.

\section{The benefits of this research are as} follows:

a. To apply the knowledge gained during education at the Naval College of Technology.

b. For KRI Commander:

1) Easily find out data and inventory details of goods.

2) Easy to supervise personnel in the use of inventory.

3) Easy to make decisions / policies based on the reports received.

4) Facilitating the commander in reporting the technical readiness of the ship.

5) Facilitating reporting of the handover of positions to the new commander.

c. For Head of Departments:

1) Speed up the process of finding detailed data regarding inventory and equipment items.

2) Speed up the loan and return administration process and report damage to goods.

3) Facilitate decision making in damage reports to units.

4) Facilitating the reporting of inventory strength to the Commander.

d. For members of the Department:

1) Speed up the process of borrowing and returning goods and avoid mistakes in taking goods.

2) Can find out the condition of the goods.

3) Make it easy to record goods in and out.

4) Simplify reporting to department heads and commanders.

5) Make it easier to make transactions of goods and monitor inventory goods. 


\section{LITERATURE REVIEW}

\subsection{System}

According Jogiyanto (2009), the system can be defined as a collection of components that are interconnected with one another to form a unity to achieve certain goals. Components in a system in general are input, processing and output. Input in the form of data to be processed in the system. Data can come from outside the organization. Output is useful information for the wearer. Outputs are created using existing data in a database and are processed using a particular model. The system also requires feedback to produce the right output for its users by evaluating the input that is processed.

A system can be interpreted as a collection or set of elements, components, or variables that are organized, interact with each other, are interdependent, and integrated. From this definition can be further detailed understanding of the system in general, namely:

a. Each system consists of elements.

b. These elements are an integrated part of the system in question.

c. The system elements work together to achieve system goals.

a. A system is part of another larger system.

\subsection{Information}

According to Jogiyanto (2009), information is data that is processed into a useful form for the wearer. According to Jogiyanto (2009), information must be supported by three pillars as follows:

a. Relevant namely the information presented must be right to the people who need it or on demand.

b. Punctual, i.e. information must be presented exactly when people need it.

c. Accurate namely the information presented must be in accordance with reality.

\subsection{Inventory Information System}

Information system is a system within an organization that meets the needs of daily transaction processing, supports operations, managerial and strategic activities of an organization and provides certain external parties with the necessary reports. According to the Big Indonesian Dictionary (KBBI), inventory is the recording or registration of items belonging to the office (schools, households, etc.) that are used in carrying out tasks.

$\mathrm{KRI}$ plays an active role in the development of military operations as well as non-military operations, so that the inventory requires very complex records both in the case of incoming and outgoing goods, sewaco data and other material goods that are still good or have been damaged for reporting technical conditions.

Upper Inventory Holder (PAI) is a soldier who is still active in serving as a supervisor and person in charge of an inventory that is tasked with monitoring inventory items in order to be able to report inventory readiness directly for occupational or operational assignment interests and is directly under the head of the department. The Office of the Commander is a compartment within the KRI that functions as a place for recording and storing all data of inventory items

in accordance with the aims and objectives, so that the inventory is kept as well as possible and as a center for all files both in the form of letters and computerized journals.

\subsection{Technical Condition Report}

According to Keraf (2001: 284), a report is a way of communicating how to convey information to someone or an agency to another agency because it is an accountability that must be carried out and reported within the allotted time. Reports contain information that is supported by complete data in accordance with the facts found and data arranged in such a way that the accuracy of the information we provide can be trusted and easily understood.

The technical condition report is an official regulation in order to carry out routine technical reports of all levels at the KRI level with the aim of reporting the ship's readiness both inventory reports and ship material reports as routine technical instructions carried out by the top command level ranks in order to prepare all ships preparedness for assignment military and non military. In the implementation of technical reports technical conditions on KRI reported every day to the unit staff and forwarded to the ship maintenance service (Disharkap). 


\subsection{Relational Database Management}

\section{System}

Relational Database Management System (RDBMS) is a computer program designed to manage or manage a base as a collection of data that is stored in a structured manner, and perform various operations on data at the request of its users. RDBMS is used to store information that can be seen in different ways by users. RDBMS consists of:

\section{a. Database}

A database is a collection of data that contains information and is interconnected. This understanding is very different between Relational and Non-Relational databases. The database is only a file.

b. Table

A table or entity in the relational model is used to support the communication interface between the user and the computer professional. In the table itself is actually a matrix of data items organized into rows and columns.

c. Record

Record or row is a collection of data consisting of one or more fields. In each of these rows stored data from the relevant table subjects. In addition, the data contained in a record can consist of various types of data.

\section{d. Field}

Field or column or in formal terms relational model called attribute is a collection of data that has / stores the same/ similar facts for each row in the table. It should be noted that the order of data in a column for each row has no meaning so that the data has no effect even if changed.

e. Index

Index is a type of a particular table that contains the values of key fields or fields specified by the user and points to the actual record location. For example, in the telephone book, an index can be used to sort information by surname and first name. Other indexes may be used to sort information based on the person's residence address.

\section{ANALYSIS AND DESIGN}

According Jogiyanto (2009), system analysis can be defined as the breakdown of complete information into its component parts with the aim of identifying and evaluating problems that occur and the needs that are expected so that improvements can be proposed.

System analysis is the most important stage of a programming because it is the initial stage to evaluate the problems that occur as well as the obstacles encountered. Effective analysis will facilitate the work of good planning in the next stage.

In the system analysis stage there are basic steps that must be performed by the system analyst, namely:

a. Understand, namely understanding the work of the existing system.

b. Analyze, which is analyzing the system.

c. Report, which makes a report of the results of the analysis.

At the design stage, problem identification and analysis are carried out to determine the factors that are problems in the existing system or use. Data from external sources (system users) are collected as material for analysis. If all problems have been identified, proceed with studying and understanding the workflow of the system used. The next step is to analyze and compare the system that will be formed with the previous system and then make a report.

\subsection{System Development Life Cycle}

\section{Model}

According to Russell Kay (2002), System Development Life Cycle (SDLC) is the process of developing or changing software systems using models and methodologies that people use to develop software systems. a phased approach to analyzing and building system designs using cycles that are specific to user activities. SDLC is also a center for developing efficient information systems.

According to Roger S. Pressman (2001), the waterfall model is a sequential software development process on picture. 


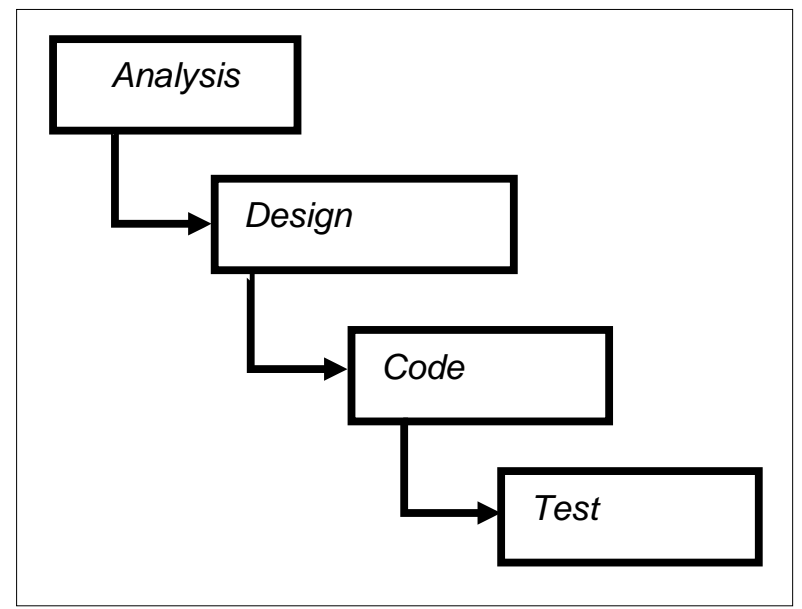

Figure 1. System Description

\section{a. Analysis}

At this stage an exploration of the needs of the client is carried out. Requirement analysis is the process of gathering software specification analysis in accordance with what is needed by the user.

b. Design

The design phase is a process that focuses on the design of software development including the design of data structures, architecture and interfaces and coding procedures. The design process translates requirements analysis into software representation before coding.

\section{c. Code}

The coding phase is the process of implementing the making of program code from software. This process translates the design that has been made into a software program. The results of this stage in the form of software in accordance with the design that has been made.

d. Test

The testing phase is the process of testing software in terms of logic and functionality to ensure that the software is functioning properly. This is also to minimize the occurrence of errors (errors) and ensure that the software produced is as desired. Based on the theory above the waterfall model can be used in software development which is carried out sequentially. The waterfall model was chosen because at each stage of the process it is easy to understand and has a systematic and orderly approach so that the research carried out is more controlled and well scheduled.

\subsection{Human and Computer Interaction}

Human and Computer Interaction (IMK) is described as a discipline that studies the design, evaluation, and implementation of interactive computer systems for human use, along with studies of the main factors in their interaction environment. Description is a study of planning and design about the way humans and computers work together so that people feel satisfied in the most effective way.

Important components of IMK are interaction, human, and computer. The types of communication include command entry, menus and navigation, forms and spreadsheets, question and answer dialogue, natural language, windows icon menu pointer, and direct manipulation.

\section{SYSTEM RESULTS AND TESTING 4.1. Software Testing}

Software testing is carried out to determine the extent of work capabilities of the inventory information system software and technical condition reports. Software testing is carried out on this system namely, the login process, the input process, the print report process, the search process, the logout process and the setting process. Testing of the inventory information system and the KRI technical condition report can be seen in table 1 . 
Table 1. Software testing.

\begin{tabular}{|c|c|c|c|c|c|c|}
\hline NO & PROGRAM & TARGET & INPUT & OUTPUT & $\begin{array}{l}\text { OUTPUT } \\
\text { PROGRAM }\end{array}$ & STATUS \\
\hline 1 & 2 & 3 & 4 & 5 & 6 & 7 \\
\hline 1. & LOGIN. & Enter program & $\begin{array}{l}\text { Rdusername, } \\
\text { Password }\end{array}$ & Program entry & Program entry & Available \\
\hline 2. & $\begin{array}{l}\text { DATA } \\
\text { PERSONEL }\end{array}$ & $\begin{array}{l}\text { Edit, delete and } \\
\text { print. }\end{array}$ & $\begin{array}{l}\text { Nrp, Name, } \\
\text { Rank, } \\
\text { Departement }\end{array}$ & $\begin{array}{l}\text { Edit, delete and } \\
\text { print. }\end{array}$ & $\begin{array}{l}\text { Edit, delete and } \\
\text { print. }\end{array}$ & Available \\
\hline 3. & $\begin{array}{l}\text { DATA } \\
\text { DEPARTEMEN } \\
\mathrm{T}\end{array}$ & $\begin{array}{l}\text { Edit, delete and } \\
\text { print.. }\end{array}$ & Code, type & $\begin{array}{l}\text { Edit, delete and } \\
\text { print.. }\end{array}$ & $\begin{array}{l}\text { Edit, delete and } \\
\text { print.. }\end{array}$ & Available \\
\hline 4. & DATA LOAN & $\begin{array}{l}\text { Edit, delete and } \\
\text { print... }\end{array}$ & $\begin{array}{l}\text { Number, date, } \\
\text { classification, } \\
\text { unit }\end{array}$ & $\begin{array}{l}\text { Edit, delete and } \\
\text { print. }\end{array}$ & $\begin{array}{l}\text { Edit, delete and } \\
\text { print. }\end{array}$ & Available \\
\hline
\end{tabular}




\subsection{Hardware Testing}

Hardware testing is carried out to determine the extent to which the work capabilities of the hardware installed on the inventory information system and the KRI Oswald Siahaan-354 technical condition report. Hardware testing carried out on this system is testing to do print printing and network testing.

Print test is carried out to find out whether the system can output from data to be issued, and network system testing is carried out to find out whether the system is connected and integrated with each other between one device and another device in a network, namely the Local Area Network ( LAN).
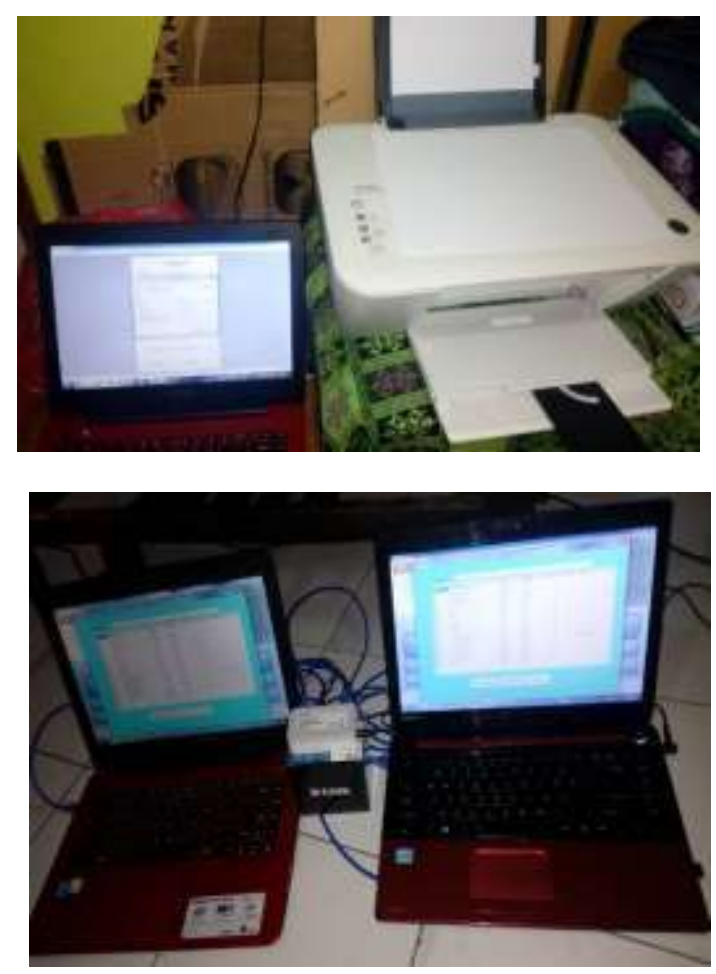

\section{CONCLUSIONS AND \\ RECOMMENDATIONS}

\subsection{Conclusion}

Based on the results of tests conducted on the design and manufacture of an inventory information system and a report on the technical conditions of KRI OSWALD SIAHAAN-354, the following conclusions are obtained:

\footnotetext{
a Inventory information system application program as well as the report on the technical conditions of the Republic of Indonesia ship (KRI) can print
}

member data, print goods data, print loan reports, print returns reports, print crash report, print PUT data, print PUS data, print ship liver data, and print technical condition report data.

b. The inventory information system application program as well as the report on the technical conditions of the Republic of Indonesia ship (KRI) can also process data input, update data, store data, and search data according to the criteria of each data in the system.

\subsection{Recomendation}

Recomendation for system development are as follows:

a. In this system can be made wireless LAN on KRI.

b. In this system, you can add another document menu form in addition to ship inventory.

c. In this system, RFID or barcode can be added to add to the item type.

\section{REFERENCES}

Departemen Pendidikan Nasional. (2008). Kamus Besar Bahasa Indonesia. Edisi ke-4. Jakarta: Gramedia Pustaka Utama.

Hartono, Rudi., \& Briyanto, Andarias. (2015). Rancang Bangun Sistem Informasi Perpustakaan Sekolah Tinggi Teknologi Angkatan Laut. Tugas Akhir STTAL.

Jogiyanto, HM. (2009). Analisis \& desain sistem informasi: Pendekatan terstruktur teori dan praktik aplikasi bisnis. Yogyakarta: Andi Offset.

Mustakini, Jogiyanto Hartono. (2009). Sistem Teknologi Informasi (Edisi III). Yogyakarta: Andi.

Russel Kay (2002), System Development Life Cycle (SDLC): A Guide to Selection and. Tylor \& Francis Goup LLC.

Prasettyo, Anggoro., \& Kurniawan, Fajar. (2015). Rancang Bangun Sistem Inventarisasi Senjata di Batalyon Tank Amfibi 1 Marinir Karangpilang 
Berbasis RFID. Tugas Akhir STTAL

Surabaya.

Sutanta, Edhy. (2011). Basis Data dalam Tinjauan Konseptual.

Yogyakarta: Andi.

\section{Sumber dari Internet:}

Ramdani, (2017). Mengenal Relasi Data base.

Retrieved Desember 2017,

from

https://spatabang.blogspot.co.id/201

3/06/cara-membuat-relasi-antar-

tabel-database.

Sukmadinata, (2005), jenis pendidikan.

Retrieved November 2017, from

https://shendud.wordpress.com/pendidikan/jen

is-ienis-penelitian/ 